\title{
Novel subtractive transcription-based amplification of mRNA (STAR) method and its application in search of rare and differentially expressed genes in AD brains
}

\author{
Qing Yan Liu*1, Roy R Sooknanan², Lawrence T Malek³, Maria Ribecco- \\ Lutkiewicz$^{1}$, Joy X Lei ${ }^{1}$, Hui Shen ${ }^{1}$, Boleslaw Lach ${ }^{4}$, P Roy Walker ${ }^{1}$, \\ Joel Martin ${ }^{5}$ and Marianna Sikorska ${ }^{1}$
}

\begin{abstract}
Address: ${ }^{1}$ Neurobiology Program, Institute for Biological Sciences, National Research Council of Canada, Ottawa, Ontario, K1A 0R6,Canada, ${ }^{2}$ Alethia Biotheraputics Inc., 8475 Christophe-Colomb Avenue, Suite 1000 Montreal, Quebec, H2M 2N9, Canada, ${ }^{3}$ Osteopharm Inc., Unit 14, 1155 North Service Road, Oakville, Ontario, L6M 3E3, Canada, ${ }^{4}$ Hamilton Health Sciences, Hamilton General Hospital, Laboratory Medicine, 237 Barton Str East, Hamilton, Ontario, L8L-2X2, Canada and 5 Interactive Information Group, Institute for Information Technology, National Research Council of Canada, Ottawa, Ontario, K1A 0R6, Canada
\end{abstract}

Email: Qing Yan Liu* - qing_yan.liu@nrc.gc.ca; Roy R Sooknanan -rnv.sooknanan@sympatico.ca; Lawrence T Malek - lm@osteopharm.com; Maria Ribecco-Lutkiewicz - maria.ribecco@nrc.gc.ca; Joy X Lei - joy.lei@nrc.gc.ca; Hui Shen - hshen01@yahoo.com; Boleslaw Lach - boleklach2@hotmail.com; P Roy Walker - roy.walker@nrc.gc.ca; Joel Martin - joel.martin@nrc.gc.ca; Marianna Sikorska - marianna.sikorska@nrc.gc.ca

* Corresponding author

Published: 07 November 2006

BMC Genomics 2006, 7:286 doi:10.1/86/147|-2164-7-286
Received: 0I May 2006

Accepted: 07 November 2006

This article is available from: http://www.biomedcentral.com//47|-2 I64/7/286

(C) 2006 Liu et al; licensee BioMed Central Ltd.

This is an Open Access article distributed under the terms of the Creative Commons Attribution License (http://creativecommons.org/licenses/by/2.0), which permits unrestricted use, distribution, and reproduction in any medium, provided the original work is properly cited.

\begin{abstract}
Background: Alzheimer's disease (AD) is a complex disorder that involves multiple biological processes. Many genes implicated in these processes may be present in low abundance in the human brain. DNA microarray analysis identifies changed genes that are expressed at high or moderate levels. Complementary to this approach, we described here a novel technology designed specifically to isolate rare and novel genes previously undetectable by other methods. We have used this method to identify differentially expressed genes in brains affected by AD. Our method, termed Subtractive Iranscription-based Amplification of mRNA (STAR), is a combination of subtractive RNA/DNA hybridization and RNA amplification, which allows the removal of nondifferentially expressed transcripts and the linear amplification of the differentially expressed genes.

Results: Using the STAR technology we have identified over 800 differentially expressed sequences in AD brains, both up- and down- regulated, compared to age-matched controls. Over $55 \%$ of the sequences represent genes of unknown function and roughly half of them were novel and rare discoveries in the human brain. The expression changes of nearly 80 unique genes were further confirmed by $q R T-P C R$ and the association of additional genes with AD and/or neurodegeneration was established using an in-house literature mining tool (LitMiner).

Conclusion: The STAR process significantly amplifies unique and rare sequences relative to abundant housekeeping genes and, as a consequence, identifies genes not previously linked to AD. This method also offers new opportunities to study the subtle changes in gene expression that potentially contribute to the development and/or progression of $A D$.
\end{abstract}




\section{Background}

Recent advance in molecular biology have introduced new high-throughput tools for the analysis of differential gene expression in complex diseases, such as Alzheimer (AD), providing simultaneous overviews of the genes or proteins associated with multiple cellular pathways. The most commonly used technology for the assessment of gene expression changes in postmortem brain is the DNA microarray [1-5] This approach has not only confirmed the involvement of genes implicated in $\mathrm{AD}$ by conventional methods, but also revealed changes in additional genes, not previously associated with $\mathrm{AD}[6,7]$. However, as this method requires a priori knowledge of gene sequences, it cannot be applied as a discovery tool for novel transcripts. Furthermore, the expression levels of low abundance genes cannot be readily assessed by DNA microarray hybridization, since reliable results are usually obtained only for genes that are expressed in high or moderate levels. This is a significant limitation since many transcripts expressed preferentially in brain (e.g., neurotransmitter receptors and their regulatory factors) are present at very low levels $[8,9]$.

Differential display and conventional subtractive hybridization approaches are capable of detecting expression changes in both known and novel genes. Differential display uses arbitrarily primed PCR to fingerprint differences (from first strand CDNA) in gene expression between two samples, with the results being determined by the intensities of bands on a polyacrylamide gel [10]. The major disadvantages of this method include its lack of sensitivity for the detection of rare RNA species, the high number of false positives generated during PCR and cloning of the differentially expressed products from low resolution polyacrylamide gels, where an apparent single band may contain multiple cDNA species. Consequently, differential display is labor intensive and unreliable for this application.

Subtractive hybridization, on the other hand, permits the isolation of target sequences from one single-stranded DNA population, referred to as "tester", from another DNA population, referred to as "driver" by using an excess of sequences. The two populations are mixed and put through iterative rounds of subtraction of cross-hybridized products. Earlier subtractive methods required physical removal of hybridized driver and tester sequences, which contributed to the loss of low abundance tester sequences. Suppression subtractive hybridization (SSH) is a newer method [11] which couples hybridization-based de-selection of common cDNAs to PCR amplification which enriches differentially expressed transcripts from two mRNA sources. In contrast to differential display, the primers for PCR amplification are clearly defined, thus avoiding problems associated with random primers. The main disadvantage of this procedure is its higher detection threshold. According to the kit manufacturer's recommendation (Clontech Palo Alto, CA), the difference in mRNA levels needs to be at least 5 fold to allow reliable detection.

Here, we have developed a novel approach to the identification of differentially expressed rare sequences through a combination of subtractive hybridization and RNA amplification, termed a Subtractive Transcription-based Amplification of mRNA (STAR). In our method, the expressed RNAs from two source are used for the preparation of specialized cDNA libraries, from which single stranded $(+)$ sense tester RNA and single stranded (-) sense driver DNA are generated. Subtraction is accomplished by the hybridization of single-stranded driver DNA to the complementary single-stranded tester RNA, followed by RNase H digestion. This process not only eliminates the necessity for physical removal of hybridized common sequence, but also eliminates the self-annealing step of the tester nucleic acids that is required by the SSH method for the amplification of target sequences. The self-annealing step usually imposes kinetic limitations and requires lengthy hybridization in order to recover rare cDNA sequences. Furthermore, in the STAR method, the tester RNA is designed with a defined terminal sequence which allows the unhybridized tester RNA to be amplified in a linear RNA amplification process, rather than exponential PCR amplification, thereby minimizing biased sequence amplification $[12,13]$ Since the tester RNA remains unchanged in the process, the products of one round of STAR are used directly in subsequent rounds to provide further enrichment of the unique sequences.

In this study, we applied the STAR method to an investigation of changes in gene expression in port-mortem $\mathrm{AD}$ brain. We show that, indeed, the STAR process significantly increases the levels of unique and rare sequences relative to abundant housekeeping genes and identified changes in the expression of genes not previously linked to the $\mathrm{AD}$. We also performed extensive literature mining to provide a basis for considering their likely involvement in neurodegenerative processes.

\section{Results \\ Characterization of the subtracted AD CDNA libraries}

Two subtracted cDNA libraries, using either the $3^{\prime}$ cDNA of the control sample (C-AD) or the $3^{\prime} \mathrm{cDNA}$ of the $\mathrm{AD}$ sample (AD-C) as tester, were prepared using the STAR method (Fig 1). It was expected that they would contain genes that were down regulated (C-AD) and up regulated (AD-C) in $\mathrm{AD}$ brain, respectively. To isolate these genes, three rounds of STAR subtraction were performed, and the remaining 3' biased cDNA tester fragments were linearly amplified, ligated into a pUC-modified vector and trans- 
formed into E. Coli DH10B cells. Approximately 5000 colonies were obtained for each STAR library. Subsequently, PCR and DNA sequencing were performed on amplified cDNA inserts from 600 individual colonies for each subtracted library. Data analysis indicated that this number of colonies was sufficient to represent the entire subtracted library since many genes, including some of low abundance, appeared to be represented by more than one colony. The results summarizing the genes found in the C$\mathrm{AD}$ and $\mathrm{AD}-\mathrm{C}$ libraries are listed in Tables 1 and 2, respectively.

Of the 600 colonies analyzed from each library, over 500 contained inserts and produced readable sequences after PCR. Sequence annotation grouped the genes into three categories: (i) known genes, (ii) ESTs and (iii) novel genes, whose sequences either only match a fragment of genomic DNA or the database search did not hit any existing known sequence. The known genes were represented by multiple colonies (Table 1, 183/266, i.e., out of 266 colonies sequenced from the C-AD library 183 were unique sequences of known genes; Table 2, 187/277 in the AD-C library) far more often than the novel genes (113/131 and 109/119), indicating that known genes are relatively more abundant than the novel genes, explaining why they are more easily identified by traditional approaches. Sequence annotation also revealed that genes involved in maintenance of neuronal cell structure and function, the ubiquitin pathway and energy metabolism were predominant in the $\mathrm{C}$-AD library, indicating that they were down regulated in $\mathrm{AD}$ brains. Whereas in the $\mathrm{AD}-\mathrm{C}$ library, genes involved in inflammation, protein translation, cytoskeleton/cell adhesion and apoptosis/ neurodegeneration were up-regulated in AD. Over $55 \%$ of the sequenced fragments in each subtracted library represented unknown genes, of which one half were not previously described as cDNA sequences. Representative data from these libraries is shown below.

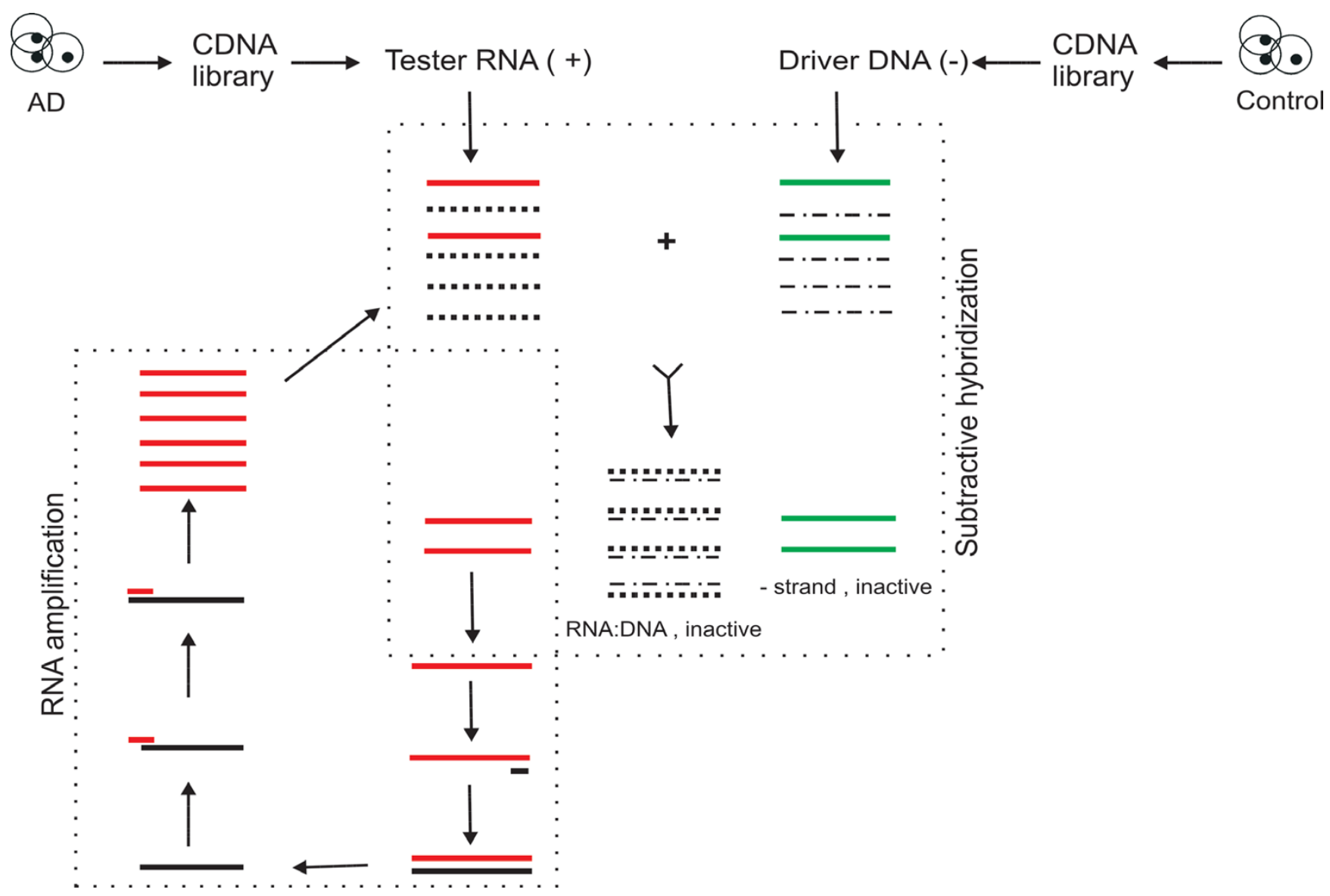

Figure I

Schematic diagram of the STAR procedure. The solid red line represents tester specific RNA (+). The solid green line indicates driver specific DNA (-). The solid black line shows newly synthesized tester specific first strand cDNA (-). Shortdashed lines show the common tester RNA (+). The long and short mixed dashed line denotes the common driver DNA (-). 
Table I: Summary of sequenced clones from the C-AD subtracted cDNA library

\begin{tabular}{cccc}
\hline Sequence type & Number of colonies sequenced & Number of unique genes & Library representation (\%) \\
\hline Known & 266 & 183 & 44.7 \\
Unknown: & 261 & 226 & 55.3 \\
ESTs & 131 & 113 & 27.6 \\
- Genomic DNA or no hit & 130 & 113 & 27.6 \\
\hline Total & 527 & 409 & 100.0 \\
\hline
\end{tabular}

\section{Validation of changes from the subtracted libraries}

More than 40 genes from the C-AD library were randomly selected for analysis by qRT-PCR using the pools of control and $\mathrm{AD}$ mRNAs as input. The results confirmed down-regulation of over $80 \%$ of them, consistent with the results of the subtracted library (Table 3 ). The data also confirmed that a majority of these genes (over $90 \%$ ) were less abundant than $\beta$-actin. Furthermore, all novel transcripts were expressed at extremely low levels, some of them at only $0.0001-2 \%$ of the abundance of $\beta$-actin (Table 3). Taken together these results indicated that the STAR method permitted the isolation of differentially expressed genes, including very rare ones. This approach also revealed the existence of large number of previously unidentified genes expressed in the human brain which appear to have a disease association.

Nearly 40 randomly selected genes from the AD-C library were also analyzed by qRT-PCR in order to further validate the library data. In this case, less than $50 \%$ of the selected transcripts were found to be up regulated, with a lower percentage of novel genes (Table 4). This might be indicative of a higher content of false positive in this library, pointing out to the necessity of independent validation prior to gene selection for down stream functional studies. One possibility for the relatively low confirmation rate of the data from the AD-C library is that the increases in the expression of unconfirmed transcripts were small and, therefore, might also be difficult to validate by qRT-PCR, although this wasn't evident in the qRT-PCR validation of down regulated genes from the C-AD library. Despite this, the technique clearly identifies novel sequences that are up regulated in $\mathrm{AD}$ brain.

\section{Supporting evidence for gene association with $A D$}

An additional approach to increase confidence in the identified genes as likely disease candidates was to mine knowledge pertaining to gene function in $\mathrm{AD}$ in the existing literature using a custom built literature mining tool, LitMiner. Using this approach, we generated short lists of genes whose association with $\mathrm{AD}$ could be further rationalized (Tables 5 and 6).

The data mining analysis identified 12 genes (Table 5 items 1-12), whose down-regulation in $\mathrm{AD}$ has been previously reported, in agreement with our results as these genes were present in the C-AD subtractive library. Furthermore, down-regulation of synuclein alpha was also confirmed by qRT-PCR analysis (Table 5 , item 12). The remaining genes on this list (items 13-37) have never been formally linked to $\mathrm{AD}$, but their possible involvement could be either inferred from the literature or from the results of the present study. For example, mutations in A2M, BRI3, EEF1A1, EIF2S2, MAPT and UBB (items 1318) have been linked to various other neurodegenerative diseases [14-19] (Similarly, ATB2B1, CDK5R1, CPLX1, NES, RAD21, ST13 and TAGLN3 (items 19-25) have been shown to be down-regulated in some brain disorders [2026] The down-regulation of 12 genes from the $\mathrm{C}-\mathrm{AD}$ library (items 26-37) was validated by qRT-PCR (Table 3 ) and a similar literature analysis further supports the potential involvement of RELN, PRKCE and SYT4 (items

Table 2: Summary of sequenced clones from the AD-C subtracted cDNA library

\begin{tabular}{cccc}
\hline Sequence type & Number of colonies sequenced & Number of unique genes & Library representation (\%) \\
\hline Known & 267 & 187 & 44.2 \\
\hline Unknown & 261 & 236 & 55.8 \\
ESTs & 142 & 127 & 30.0 \\
\hline Genomic DNA or no hit & 119 & 109 & 25.8 \\
\hline Total & 528 & 423 & 100.0
\end{tabular}


Table 3: Summary of qRT-PCR analysis of the selected genes from the C-AD library

\begin{tabular}{|c|c|c|c|c|}
\hline Name & Acc \# & Gene Description & \% Down & Abundance relative to $\beta$-actin* \\
\hline & AF498312 & integrin-linked kinase I (ILK) & $29 \%$ & $19.00 \%$ \\
\hline ANK2 & NM 020977 & ankyrin2, transcript varient 2 & no change & $11.00 \%$ \\
\hline GABRB3 & $\underline{\text { CR749803 }}$ & Gamma-aminobutyric acid A receptor, beta 3 & no change & $98.00 \%$ \\
\hline \multirow[t]{2}{*}{ UBE2B } & NM 003337 & ubiquitin-conjugating enzyme E2B & $45 \%$ & $33.00 \%$ \\
\hline & AY339422 & NADH dehydrogenase sububit 3 & $30 \%$ & $475.00 \%$ \\
\hline TPII & $\mathrm{BC} 017917$ & triosephosphate isomerase & $41 \%$ & $208.00 \%$ \\
\hline BCASI & NM 003657 & breast carcinoma sequence I & $20 \%$ & $71.00 \%$ \\
\hline E46L & AK095309 & Ataxin- 10 & no change & $58.00 \%$ \\
\hline SCAI & NM 000332 & spinocerebellar ataxia I & $68 \%$ & $3.00 \%$ \\
\hline DEAFI & $\underline{\mathrm{BC} 053322}$ & transcriptional regulator protein, suppressin & $24 \%$ & $7.00 \%$ \\
\hline HLF & $\underline{M 95585}$ & hepatic leukemia factor(HLF) & no change & $0.70 \%$ \\
\hline CKIP-I & $\underline{\mathrm{BC} 010149}$ & TNF intracellular domain-interacting protein & $35 \%$ & $2.00 \%$ \\
\hline SNCA & NM 000345 & synuclein, alpha SNCA & $68 \%$ & $0.20 \%$ \\
\hline CRII & AL357456 & CREBP/EP300 inhibitory protein Ior RBP2I & $19 \%$ & $170.00 \%$ \\
\hline SYT4 & $\underline{\mathrm{BC} 036538}$ & synaptotagmin IV & $58 \%$ & $74.60 \%$ \\
\hline ARF6 & $\underline{\mathrm{BC} 030291}$ & ADP-ribosylation factor 6, Arp6 & $59 \%$ & $0.82 \%$ \\
\hline \multirow[t]{2}{*}{ PRKCE } & $\mathrm{BC} 054052$ & protein kinase $\mathrm{C}$, epsilon $Y$ & $15 \%$ & $16.90 \%$ \\
\hline & $\mathrm{BC} 000143$ & ELMO2 engulfment and cell motility 2 & $55 \%$ & $0.07 \%$ \\
\hline SV2A & $\underline{\mathrm{BC} 045111}$ & synaptic vesicle glycoprotein $2 \mathrm{~A}$ & $19 \%$ & $2.00 \%$ \\
\hline \multirow[t]{22}{*}{ RELN } & NM 005045 & reelin & $82 \%$ & $1.20 \%$ \\
\hline & $\underline{\mathrm{BC} 042904}$ & hypothetical protein DKFZp564AI76 & $15 \%$ & $22.20 \%$ \\
\hline & NM I52722 & hypothetical protein FLJ25530 & no change & $225.00 \%$ \\
\hline & AK056024 & EST & $49 \%$ & $10.60 \%$ \\
\hline & DR005162 & EST & $21 \%$ & $1163.00 \%$ \\
\hline & ALI625II & genomic DNA & $49 \%$ & $26.00 \%$ \\
\hline & AC09686I & genomic DNA & $19 \%$ & $16.00 \%$ \\
\hline & $\underline{A C l} 45098$ & genomic DNA & $41 \%$ & $12.00 \%$ \\
\hline & $\underline{A L 590482}$ & genomic DNA & $86 \%$ & $0.150 \%$ \\
\hline & $\underline{A L I 21908}$ & genomic DNA & $18 \%$ & $0.0050 \%$ \\
\hline & $\underline{A L 513318}$ & genomic DNA & $47 \%$ & $0.0002 \%$ \\
\hline & AC099787 & genomic DNA & $100 \%$ & $0.0012 \%$ \\
\hline & AL354884 & genomic DNA & $100 \%$ & $0.0012 \%$ \\
\hline & $\underline{A C I 19800}$ & genomic DNA & $50 \%$ & $0.0003 \%$ \\
\hline & AC092631 & genomic DNA & $40 \%$ & $0.0002 \%$ \\
\hline & $\underline{A L I 38753}$ & genomic DNA & $74 \%$ & $0.0002 \%$ \\
\hline & AL356608 & genomic DNA & $76 \%$ & $0.0020 \%$ \\
\hline & $\mathrm{ACl} 06856$ & genomic DNA & $17 \%$ & $0.0001 \%$ \\
\hline & AC01207I & genomic DNA & no change & $0.0290 \%$ \\
\hline & $\underline{\mathrm{ACl} 12717}$ & genomic DNA & $39 \%$ & $0.0019 \%$ \\
\hline & $\mathrm{AP} 002803$ & genomic DNA & $64 \%$ & $0.0140 \%$ \\
\hline & ALI58212 & genomic DNA & no change & $0.0002 \%$ \\
\hline
\end{tabular}

* Abundance relative to $\beta$-actin was calculated using a relative quantitation formula $: 2^{-\Delta C t} x \%$, where $\Delta C t$ is the qRT-PCR cycle number of target gene minus the qRT-PCR cycle number of $\beta$-actin at threshold in the same round of qRT-PCR experiment using cDNA from control brains. 
Table 4: Summary of qRT-PCR analysis of the selected clones from the AD-C library

\begin{tabular}{|c|c|c|c|c|}
\hline Name & Acce \# & Description of matched genes & $\% U_{p}$ & Abundance relative to $\beta$-actin \\
\hline USPIO & NM 005153 & ubiquitin specific protease 10 & $38 \%$ & $12.50 \%$ \\
\hline FNBP2 & $\underline{X M \quad 059095}$ & formin binding protein 2 & $19 \%$ & $1.10 \%$ \\
\hline LMNA & NM 170708 & $\operatorname{lamin} \mathrm{A} / \mathrm{C}$ & $36 \%$ & $6.0 \%$ \\
\hline RPS20 & NM 001023 & ribosomal protein $\mathrm{S} 20$ & $23 \%$ & $12 \%$ \\
\hline PREPL & $\underline{\mathrm{AB} 007896}$ & prolyl endopeptidase-like & $25 \%$ & $21.90 \%$ \\
\hline SKPIA & NM 170679 & cyclin A/CDK2-associated protein pl9 & $41 \%$ & $67 \%$ \\
\hline MARK2 & $\underline{\mathrm{BC} 008771}$ & ELKL motif kinase & $32 \%$ & $0.84 \%$ \\
\hline AHCTFI & AB059277 & AT hook containing transcription factor I & $60 \%$ & $10.90 \%$ \\
\hline PLRGI & $\underline{\mathrm{BC} 020786}$ & pleiotropic regulator I & $32 \%$ & $0.34 \%$ \\
\hline APRIN & NM 015032 & androgen-induced proliferation inhibitor & $32 \%$ & $19.80 \%$ \\
\hline CENTG2 & NM 014914 & centaurin, gamma 2 & $41 \%$ & $6.60 \%$ \\
\hline SCARB2 & NM 005506 & scavenger receptor class $\mathrm{B}$, member 2 & $42 \%$ & $416 \%$ \\
\hline SPTBN2 & NM 006946 & spectrin, beta, non-erythrocytic 2 & $47 \%$ & $34.50 \%$ \\
\hline SEPT6 & NM 015129 & septin 6 & $27 \%$ & $59 \%$ \\
\hline SAFB & NM 002967 & scaffold attachment factor B & $42 \%$ & $7.10 \%$ \\
\hline DRDIIP & NM 015722 & dopamine receptor DI interacting protein & $40 \%$ & $26 \%$ \\
\hline ARHGAPI & NM 004308 & Rho GTPase activating protein I & $26 \%$ & $241 \%$ \\
\hline KNS2 & NM 005552 & kinesin $260 / 70 \mathrm{kDa}$, transcript variant I & no change & $4.10 \%$ \\
\hline KIAAI078 & NM 203459 & calmodulin regulated spectrin-associated protein I-like I & no change & $25 \%$ \\
\hline ANKMY2 & $\underline{\mathrm{BC} 035353}$ & ankyrin repeat and MYND domain containing 2 & no change & $17 \%$ \\
\hline $\mathrm{FBXO33}$ & $\underline{\mathrm{BC} 053537}$ & F-box protein 33, mRNA & no change & $0.78 \%$ \\
\hline KLHDC2 & NM 014315 & kelch domain containing 2 & no change & $100 \%$ \\
\hline $\mathrm{RPRCI}$ & NM 018067 & arginine/proline rich coiled-coil I & no change & $28 \%$ \\
\hline $\mathrm{HSPHI}$ & NM 006644 & heat shock 105kD & no change & $48 \%$ \\
\hline C2I orf33 & NM 004649 & chromosome $2 \mathrm{I}$ open reading frame 33 & no change & $48 \%$ \\
\hline MBDI & AFI2098I & methyl-CpG binding domain protein I & no change & $0.49 \%$ \\
\hline STXBPI & NM 003165 & syntaxin binding protein I & no change & $93.00 \%$ \\
\hline NEKI & $\underline{A F I 55 I 13}$ & NY-REN-55 antigen & no change & $12.30 \%$ \\
\hline ASBI & NM 016114 & ankyrin repeat and SOCS box-containing I & no change & $9.10 \%$ \\
\hline \multirow[t]{9}{*}{$\mathrm{CCNI}$} & NM 006835 & cyclin I & no change & $49 \%$ \\
\hline & $\underline{A L 109709}$ & EST & no change & $22 \%$ \\
\hline & $\underline{\mathrm{BC} 035832}$ & EST & $17 \%$ & $521 \%$ \\
\hline & $\underline{\mathrm{AP} 002833}$ & genomic DNA & no change & $6.30 \%$ \\
\hline & $\underline{\mathrm{ACl} 104964}$ & genomic DNA & no change & $33 \%$ \\
\hline & $\underline{\mathrm{AP} 002833}$ & genomic DNA & $35 \%$ & $0.06 \%$ \\
\hline & $\underline{A L I 387 \mid 8}$ & genomic DNA & $50 \%$ & $0.0032 \%$ \\
\hline & $\underline{A C 091609}$ & genomic DNA & no change & $0.01 \%$ \\
\hline & AL953889 & genomic DNA & no change & $1.60 \%$ \\
\hline
\end{tabular}


Table 5: A short list of down regulated genes and supporting evidence for their involvement in AD

\begin{tabular}{|c|c|c|c|c|}
\hline Item & Name & Acce \# & Gene Description & Evidence for Down Regulation \\
\hline 1 & APP & BC065529 & amyloid beta (A4) precursor protein & literature, [2], Down regulation in DS, [65] \\
\hline 2 & CAST & NM 015576 & CAZ-associated structural protein & literature, [40] \\
\hline 3 & CD59 & $\mathrm{BC} 001506$ & CD59 antigen p $18-20$ & literature, [66] \\
\hline 4 & CDCIO & BX648365 & cell division cycle 10 & literature, [67] \\
\hline 5 & HKI & NM 033500 & hexokinase I & literature, [68] \\
\hline 6 & PFKP & $\mathrm{BC} 002536$ & phosphofructokinase & literature, [37] \\
\hline 7 & PTPNII & NM 002834 & protein tyrosine phosphatase, non-receptor type II & literature, [69] \\
\hline 8 & RPIP8 & $\underline{\mathrm{BC} 013240}$ & RaP2interacting protein 8 & literature, [3] \\
\hline 9 & SCD & NM 005063 & stearoyl-CoA desaturase & literature, $[70]$ \\
\hline 10 & SERPINE2 & NM 006216 & serine (or cysteine) proteinase inhibitor, clade $\mathrm{E}$, member 2 & literature, $[4 I]$ \\
\hline 11 & UCHLI & $\mathrm{BC} 000332$ & ubiquitin thiolesterase, $\mathrm{UCHLI}$ & literature $[71,72]$. \\
\hline 12 & SNCA & NM 000345 & synuclein, alpha & qRT-PCR, literature, [2] \\
\hline 13 & $\mathrm{~A} 2 \mathrm{M}$ & $\underline{\mathrm{BC} 04007 \mathrm{I}}$ & alpha-2-macroglobulin & mutation of $A 2 M$ is linked to $A D,[16]$ \\
\hline 14 & $\mathrm{BRI3}$ & BC018737 & Brain protein 13 & $\begin{array}{l}\text { mutation of BRI2 is liked to } \\
\text { neurodegeneration[19] }\end{array}$ \\
\hline 15 & EEFIAI & BC009875 & Eukaryotic translation elongation factor I alpha I & $\begin{array}{l}\text { mutation, mutant mice exhibit } \\
\text { neurodegeneration, }[14]\end{array}$ \\
\hline 16 & EIF2S2 & $\underline{\mathrm{BC} 000461}$ & Eukaryotic translation initiation factor 2 , subunit 2 beta & $\begin{array}{l}\text { mutation, mutations causing childhood ataxia, } \\
\text { [15] }\end{array}$ \\
\hline 17 & MAPT & $\underline{\mathrm{BC} 032572}$ & microtubule-associated protein tau, long splice form & $\begin{array}{l}\text { mutation, mutation in exon } 9-13 \text { cause } \\
\text { neurodegenerative diseases including } A D,[18]\end{array}$ \\
\hline 18 & UBB & $\underline{\mathrm{BC} 038999}$ & ubiquitin $\mathrm{B}$ & mutation, frame shift mutation fund in $A D,[17]$ \\
\hline 19 & ATP2BI & $\underline{A K 024895}$ & ATPase, $\mathrm{Ca}++$ transporting, plasma membrane I & inferred, expression is repressed by stress, [2I] \\
\hline 20 & CDK5RI & BC035448 & cyclin-dependent kinase 5, regulatory subunit I & $\begin{array}{l}\text { inferred, [73], and in ethanol induced } \\
\text { neurodegeneration, [23] }\end{array}$ \\
\hline 21 & CPLXI & BC00247I & complexin I & inferred, Down regulated in schizophrenia, [24] \\
\hline 22 & NES & AF086454 & nestin & $\begin{array}{l}\text { inferred, decreased in injured aged hippocampus, } \\
\text { [20] }\end{array}$ \\
\hline 23 & RAD2I & NM 006265 & RAD2I homolog & inferred, Down regulated by hypoxia, [26] \\
\hline 24 & STI3 & BC052982 & suppression of tumorigenicity 13 & $\begin{array}{l}\text { inferred, rescue phosphorylated tau-induced cell } \\
\text { death [25] }\end{array}$ \\
\hline 25 & TAGLN3 & AF303058 & transgelin 3 & inferred, down regulated in schizophrenia, [22] \\
\hline 26 & ARF6 & $\mathrm{BC} 030291$ & ADP-ribosylation factor 6 & qRT-PCR \\
\hline 27 & BCASI & NM 003657 & Breast carcinoma amplified sequence I & qRT-PCR \\
\hline 28 & CKIP-I & $\mathrm{BC} 010149$ & CK2 interacting protein I & qRT-PCR \\
\hline 29 & CRII & AL357456 & CREBP/EP300 inhibitory protein I & qRT-PCR \\
\hline 30 & DEAFI & $\mathrm{BC} 053322$ & deformed epidermal autoregulatory factor I & qRT-PCR \\
\hline 31 & SCAI & NM 000332 & spinocerebellar ataxia I & qRT-PCR \\
\hline 32 & $\mathrm{SV} 2 \mathrm{~A}$ & $\underline{\mathrm{BC} 045111}$ & synaptic vesicle glycoprotein $2 \mathrm{~A}$ & qRT-PCR \\
\hline 33 & TPII & $\underline{\mathrm{BC} 017917}$ & triosephosphate isomerase & qRT-PCR \\
\hline 34 & UBE2B & NM 003337 & ubiquitin-conjugating enzyme E2B & qRT-PCR \\
\hline 35 & RELN & NM 005045 & reelin & $\begin{array}{l}\text { QRT-PCR and inferred, down regulation or } \\
\text { mutation cause autistic disorder, [27] }\end{array}$ \\
\hline 36 & PRKCE & BC054052 & protein kinase $\mathrm{C}$, epsilonY & $\begin{array}{l}\text { qRT-PCR and inferred, suppresses } A \beta \\
\text { production, }[28]\end{array}$ \\
\hline 37 & SYT4 & $\underline{\mathrm{BC} 036538}$ & synaptotagmin IV & $\begin{array}{l}\text { qRT-PCR, inferred, SYT(unspecified isoform) is } \\
\text { down regulated in CAI of AD brains, [2] }\end{array}$ \\
\hline
\end{tabular}




\begin{tabular}{|c|c|c|c|c|}
\hline Item & Name & Acce \# & Gene Description & Evidence for Down Regulation \\
\hline I & CLU & NM 001831 & clusterin & literature, $[30,34]$ \\
\hline 2 & GFAP & NM 002055 & glial fibrillary acidic protein & literature, [29] \\
\hline 3 & $\mathrm{CP}$ & NM 000096 & ceruloplasmin & literature, [53] \\
\hline 4 & DYRKIA & NM 001396 & dual-specificity tyrosine-(Y) phosphorylationregulated kinase IA & literature, $[74]$ \\
\hline 5 & FKBPIA & $\overline{N M 000801}$ & FK506 binding protein IA & literature, [57] \\
\hline 6 & FTL & $\underline{\mathrm{BC} 058820}$ & ferritin, light polypeptide & literature $[3,34,52]$ \\
\hline 7 & M6PR & NM 002355 & mannose-6-phosphate receptor & literature, $[75]$ \\
\hline 8 & MAP2 & NM 031846 & microtubule-associated protein 2 & literature, [3] \\
\hline 9 & MBP & $\mathrm{BC} 008749$ & myelin basic protein & literature, [49] \\
\hline 10 & MTIF & NM 005949 & metallothionein IF & literature, $[31]$ \\
\hline 11 & RPL23 & $\mathrm{BC} 010114$ & ribosomal protein $\mathrm{L} 23$ & literature, [3] \\
\hline 12 & RPS27 & NM 001030 & ribosomal protein S27 & literature, [76] \\
\hline 13 & VDAC2 & $\overline{N M 003375}$ & voltage-dependent anion channel 2 & literature, [77] \\
\hline 14 & YWHAE & $\mathrm{BC001440}$ & $\begin{array}{l}\text { tyrosine 3-monooxygenase/tryptophan-5-monooxygenase activation } \\
\text { protein, epsilon polypeptide }\end{array}$ & literature, [78] \\
\hline 15 & AGT & NM 000029 & angiotensinogen & literature, $[34,79]$ \\
\hline 16 & STXBPI & $\overline{N M 003165}$ & syntaxin binding protein I & literature, $[3,32]$, qRT-PCR did not show significant change \\
\hline 17 & KNS2 & $\overline{\mathrm{BC} 008881}$ & kinesin $260 / 70 \mathrm{kDa}$ & inferred, up regulated in injured optic nerve, [33], qRT-PCR did not show significant change \\
\hline 18 & $\mathrm{C} 21$ orf33 & NM 004649 & chromosome 21 open reading frame 33 & inferred, elevated in fetal Down syndrome brain, $[80]$ \\
\hline 19 & FKBP2 & $\overline{N M 057092}$ & FK506 binding protein 2 & inferred, [57] \\
\hline 20 & FREQ & NM 014286 & frequenin homolog & inferred, up in Schizophrenia, [8I] \\
\hline 21 & GRM3 & NM 000840 & glutamate receptor, metabotropic 3 & inferred, GRM2 and 4 increased in ischemic neurodegeneration, [82] \\
\hline 22 & NPTXI & NM 002522 & neuronal pentraxin I & inferred, short pentraxins are upregulated in $A D,[50]$ \\
\hline 23 & PDE8A & NM 002605 & phosphodiesterase $8 \mathrm{~A}$ & inferred, family member of PDE8B, is upregulated in AD, [83] \\
\hline 24 & AHCTFI & $A B 059277$ & AT hook containing transcription factor I & qRT-PCR \\
\hline 25 & APRIN & NM 015032 & androgen-induced proliferation inhibitor & qRT-PCR \\
\hline 26 & CENTG2 & NM 014914 & centaurin, gamma 2 & qRT-PCR \\
\hline 27 & LMNA & NM 170708 & $\operatorname{lamin} \mathrm{A} / \mathrm{C}$ & qRT-PCR \\
\hline 28 & PLRGI & $\underline{\mathrm{BC} 020786}$ & pleiotropic regulator I & qRT-PCR \\
\hline 29 & PREPL & $\mathrm{AB} 007896$ & prolyl endopeptidase-like & qRT-PCR \\
\hline 30 & RPS20 & NM 001023 & ribosomal protein $\$ 20$ & qRT-PCR \\
\hline 31 & SAFB & NM 002967 & scaffold attachment factor B & qRT-PCR \\
\hline 32 & SPTBN2 & NM 006946 & spectrin, beta, non-erythrocytic 2 & qRT-PCR \\
\hline 33 & SRGAP2 & $\underline{\underline{X M} 059095}$ & SLIT-ROBO Rho GTPase activating protein 2 & qRT-PCR \\
\hline 34 & USPIO & $\overline{N M 005153}$ & ubiquitin specific protease 10 & qRT-PCR \\
\hline 35 & ARHGAPI & NM 004308 & Rho GTPase activating protein I (CDC42GAP) & QRT-PCR, inferred, CDC42 is upregulated in AD, [60] \\
\hline 36 & DRDIIP & NM 015722 & dopamine receptor DI interacting protein & QRT-PCR, inferred, up regulated in schizophrenia, [84] \\
\hline 37 & MARK2 & $\underline{\mathrm{BC} 008771}$ & MAP/microtubule affinity-regulating kinase 2 & qRT-PCR, inferred, [85] \\
\hline 38 & SCARB2 & NM 005506 & scavenger receptor class $\mathrm{B}$, member $2, \mathrm{CD} 36$ antigen & qRT-PCR, Inferred, inflammation increases CD36 mRNA, thus induceCD36 antigen, [5I] \\
\hline 39 & SEPT6 & NM 015129 & septin 6 & QRT-PCR, inferred, increased in motor deficient mice,[86] \\
\hline 40 & SKPIA & NM 170679 & S-phase kinase-associated protein IA & $\begin{array}{l}\text { QRT-PCR, inferred, overexpression of SKPIA together with APP increase the production of } \\
A \beta,[87]\end{array}$ \\
\hline
\end{tabular}


$35-37)[2,27,28]$ Therefore, it is likely that the down-regulation and the loss of these gene functions could play a role in $\mathrm{AD}$.

Table 6 contains a short list of genes cloned from AD-C subtractive library and supporting evidence for their role in AD. Sixteen of these genes (Table 6, items 1-16) have been previously associated with AD. For example, up-regulation of CLU, GFAP, MT1F (items 1, 2 and 10, respectively) have often been reported in AD brains [29-31] This is consistent with our data from the AD-C library. Two separate groups, Takahashi et al 2000 [32] and Loring et al 2001 [3], reported up-regulation of STXBP1 (item 16) in $\mathrm{AD}$ and the transcript of KNS2 (item 17) was reported elevated in injured optic nerve [33]. Both genes were found in the AD-C library and KNS2 was represented by multiple clones; however, we could not validate these changes by qRT-PCR (Table 5). Seven genes from this list (Table 6, items 17-23), have been shown to be elevated in other neurological disorders such as Schizophrenia, Down syndrome and ischemic neurodegeneration. Changes in the additional 17 genes (Table 6, items 2440 ) were validated by qRT-PCR, six of which (items 35$40)$ could be also inferred from the literature.

Possible associations between the 37 down-regulated (Fig. 2) and 40 up-regulated (Fig. 3) genes from the sub- tracted libraries were mapped by additional literature mining. We imported the Unigene names of each group of genes into LitMiner and used "Alzheimer" and "neurodegeneration" as knowledge terms. All articles containing a gene name, or alias and the knowledge terms, in either title, MeSH terms or abstract were reported in a graphic format. Any two given genes or a gene and one of the knowledge terms appearing in the same article were considered to constitute an association. The frequencies of these associations are represented by the number adjacent to the connecting lines. Within LitMiner, we could rapidly retrieve and manually scan articles to eliminate false association due to the misuse of gene aliases in the database. The graphs in Figs 2 and 3 contain genes that exhibited actual association to the knowledge terms or to other genes. Some genes summarized in Table 5 and 6 are not included in Figs 2 and 3 because the current software finds only associations identified in the title, abstract or MeSH terms. Nevertheless, the LitMiner output gives a high level overview of the relationships of these differentially expressed genes that is not obtainable from a simple gene list.

\section{Discussion}

With the advent of high throughput genomics and proteomics technologies, the involvement of new genes in $\mathrm{AD}$ continues to emerge, indicating clearly that the full

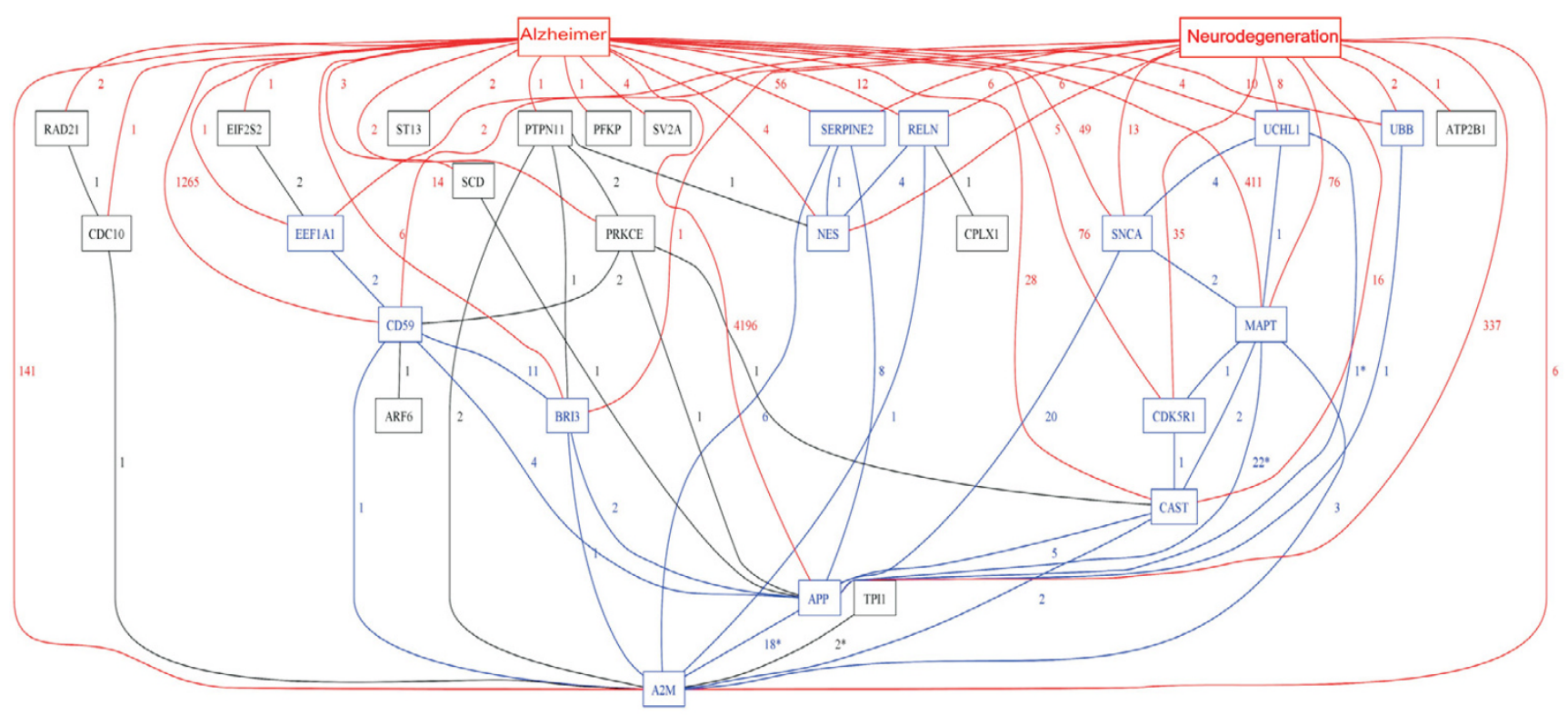

Figure 2

Association of down regulated genes with AD and neurodegeneration. The associations between genes or between genes and knowledge term (Alzheimer or Neurodegeneration) are represented as a graph with the frequency indicated by numbers on the links. A red box or line indicates a knowledge term or a link between a gene and a knowledge term, respectively. A blue box and line shows a gene that is associated with both knowledge terms. A black box and line denotes a gene that is associated with only one knowledge term or another gene. 


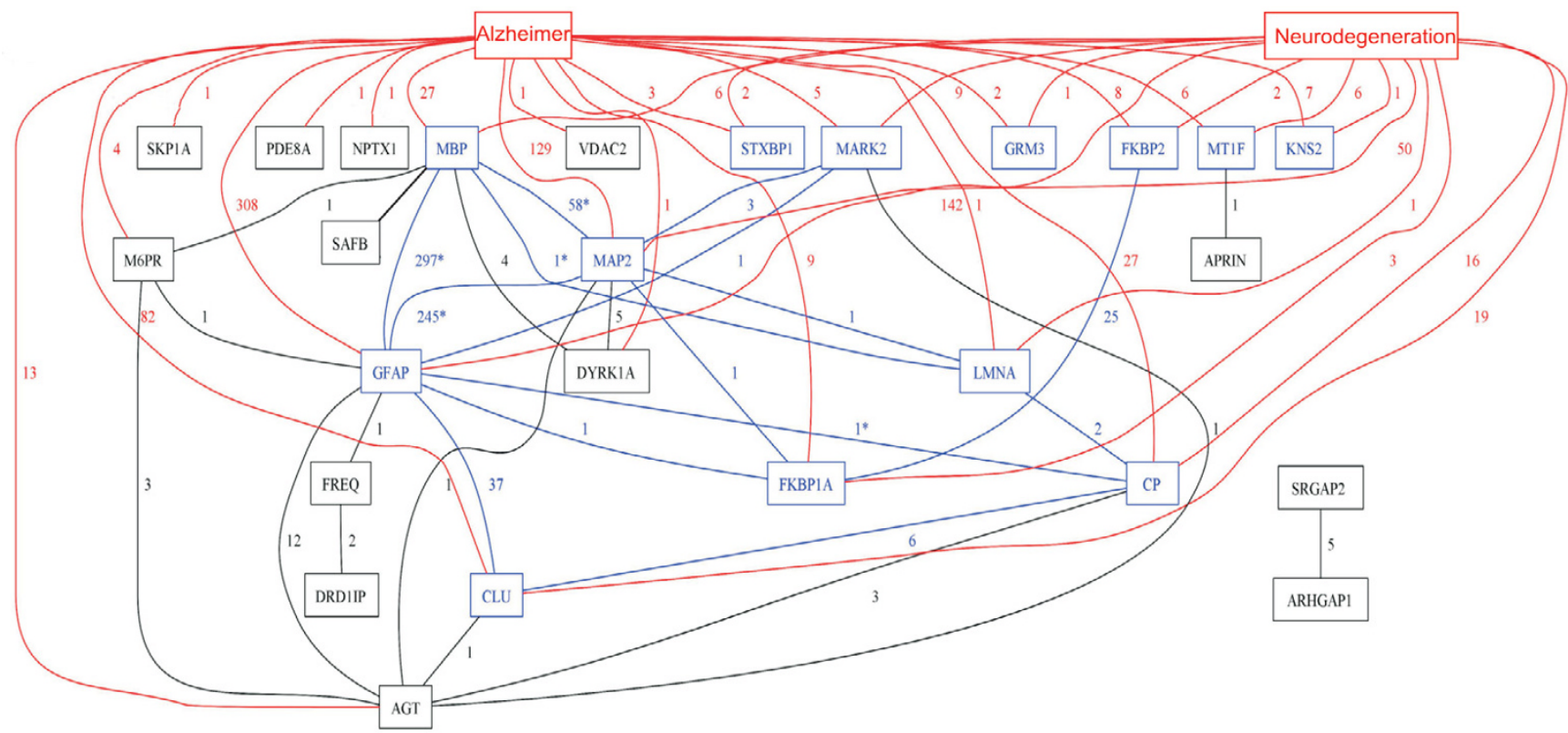

Figure 3

Association of up regulated genes with AD and neurodegeneration. The associations between genes or between genes and knowledge term (Alzheimer or Neurodegeneration) are represented as a graph with the frequency indicated by numbers on the links. A red box or line indicates a knowledge term or a link between a gene and a knowledge term, respectively. A blue box and line shows a gene that is associated with both knowledge terms. A black box and line denotes a gene that is associated with only one knowledge term or another gene.

extent of molecular and functional aberrations responsible for the etiology of AD is not yet understood. The current high throughput methods are mainly designed to identify changes in relatively abundant genes, whereas weakly expressed genes or proteins are still overlooked. For example, cDNA microarrays, although widely used, are limited to known mRNA sequences or ESTs, thus it is not suitable for the identification and isolation of novel rare transcripts. Complementary to microarray technology, subtractive hybridization is capable of detecting changes of both known and novel genes. The existing SSH method enriches the differentially expressed genes by selectively suppressing the amplification of non-differentially expressed transcripts in the PCR reaction, resulting in the enrichment of differentially expressed transcripts. An annealing step is necessary for PCR amplification and subsequent cloning and since rare sequences re-anneal more slowly, this process reduces their chances of discovery. The STAR technology uses single strand RNA/DNA hybridization to remove non-differentially expressed genes. Rare sequences are enriched by slower hybridization and the non-hybridized RNA is recovered and amplified by a linear RNA amplification procedure, which minimizes the biased exponential amplification of subsets of genes in a mixture. These features make the STAR method attractive for examining changes of gene expression in normal and diseased brain tissues, where many
mRNAs are present in low abundance. In the present study, we used the STAR method to identify genes that are not only novel in human brains, but also differentially expressed in AD. Our subtracted cDNA libraries constructed by the STAR technology contained genes whose relative differences in expression levels ranged from $25 \%$ to $100 \%$, illustrating the fidelity of this method. Although there has been little, and in some cases, no overlap in identified genes between different microarray studies of $\mathrm{AD}$ samples, due to experimental variability, different sources of microarray bearing different sets of genes and different areas of brain tissues used, STAR has identified a number of known, moderately abundant genes, whose alternation in $\mathrm{AD}$ was in agreement with previous microarray analyses. Of these APP and SNCA were found down regulated [2], AGT [34], CLU [34], FTL [3,34], MAP2 and STXBP1 [3] were reported up-regulated. More than 55\% of clones in each subtracted library contain cDNA of unknown function and more then $25 \%$ are novel sequences only matching genomic DNA in database searches. These novel genes can now be vigorously pursued to identify their function and precise role in $\mathrm{AD}$ pathology.

Similar to other high throughput approaches, the changes in gene expression identified by the STAR method need to be validated by qRT-PCR. This is especially true for the 
rare and novel sequences, for which there is no information available in the literature. Combinations of PCRselected cDNA subtraction and cDNA microarray analysis of the subtracted clones, or using probes generated by PCR-selected subtraction to screen Affymetrix GeneChips have been attempted $[35,36]$. The clones produced by STAR can be printed on microarray slides for hybridization with labeled cDNAs from individual brains samples, however, the rare RNA species must be enriched by amplification in order to give reliable hybridization signals. This method, currently under development, could be a high throughput approach to eliminate false positives before qRT-PCR validation on individual genes. We have measured changes in nearly 40 genes from each subtracted cDNA library by qRT-PCR. However, there was a difference in the confirmation rate between the two subtracted libraries. Besides the fact that there seemed to be more down- than up- regulated genes in the $\mathrm{AD}$ brains where neurodegeneration was already evident $[2,3]$., we cannot offer an definite explanation why some genes, such as, Syntaxin binding protein 1 and kinesin 2 found up-regulated by STAR procedure, consistent with the results obtained by others $[3,32,33]$, yet not confirmed by qRT-PCR. Further investigations with different fine-tuned qRT-PCR primers and conditions and by using individual brain samples may offer insight on this issue.

While identification of novel genes functions in neurodegeneration remains to be our ongoing objective, the current study was focused on the association of some of the known genes with $\mathrm{AD}$. Among the down regulated genes in Table 5, those belonging to two major functional categories are noteworthy. The first group contains genes involved in maintenance of neuronal cell function, including CAST, PFRK, SERPINE2, SNCA, SV2A and SYT4 [2,37-41] Their roles in normal brain are to promote neurite outgrowth and to regulate synaptic vesicle transport or trafficking at the synapse. Their down regulation is consistent with the compromised synaptic transmission observed in $\mathrm{AD}$ brain. This undoubtedly contributes to the impairment of memory and cognitive function. Our findings support the current view that $\mathrm{AD}$ is a disease of synaptic failure [42].

The second group of genes consists of members of the ubiquitin pathway involved in protein degradation. Although only UBB, UBE2B and UCHL1 passed our current screening criteria, several other ubiquitin pathwayrelated genes also appeared in the C-AD library. A straightforward interpretation of this result would be that the decreased ability of protein degradation caused by the down regulation of ubiquitin pathway genes, resulted in the accumulation of unwanted proteins in the senile plaques and neurofibrillary tangles. However, studies of individual ubiquitin pathway genes, such as UCHL1, sug- gest other mechanisms. For example, UCHL1 is sensitive to redox changes and is oxidized in AD brain $[43,44]$. indicating that its function under stressed conditions is more than "house keeping" [45]. Elevated expression of other ubiquitin pathway proteins in response to oxidative stress has also been documented. [46,47] However, a better understanding of the role of individual ubiquitin pathway genes in $\mathrm{AD}$ pathology requires comprehensive study.

Extensive evidence suggests that inflammation plays a major role in $\mathrm{AD}$ [48]. It is therefore not surprising to find genes, such as MBP, NPTX1 and SCARB2 involved in neuroinflammation [49-51], to be up regulated in AD brains (Table 6). We also found several genes related to the cellular distribution of iron (FTL), transport of copper (CP) and metal-binding (MT1F) that were up-regulated in AD (Table 6). [31,52,53] These data strongly suggest a disruption of metal homeostasis and a potential metal neurotoxicity component in $\mathrm{AD}$. The increase of these proteins may indicate an acute phase-type reaction and/or a compensatory response to stress conditions.

We did not find any typical cytoskeletal proteins, such as members of the actin or tubulin families, to be significantly up-regulated in AD brain. However, we did identify three clusters of genes related to cytoskeletal organization (Table 6). The first group contains organelle membrane skeletal proteins such as SAFA, LMNA and SPTBN2 [54$56]$ The second group encodes skeletal binding proteins, including FKBP2, interacting with erythrocyte membrane cytoskeletal protein [57], KNS2 and MAP2, all associated with microtubules $[58,59]$ The third group contains GTPase activating proteins, ARHGAP1, CENTG2 (AGAP1), SRGAP2, which regulate membrane trafficking and actin remodeling [60-62] SEPT6 can also be categorized into this group since it is a polymerizing GTPase required for cytokinesis and cortical organization [63]. It is intriguing that so many cytoskeleton related genes are up regulated in the degenerating brains. It is currently unclear whether these changes were the causes or the consequences of neurodegeneration. One possibility is that these genes might be up regulated in activated microglia or astrocytes, which triggered signals that mediate cytoskeletal reorganization and vesicular trafficking during glial cell migration.

\section{Conclusion}

We have used a proprietary subtractive hybridization technology (STAR) to identify differentially expressed genes in $\mathrm{AD}$ brains, extending existing gene profiling and subtraction methods, such as DNA or protein microarray analyses to identify rare sequences. $55 \%$ of the identified differentially expressed genes have no known function, of which, $25 \%$ had no matching ESTs in the databases. These sequences represented novel and newly discovered tran- 
scripts in the brain and were also differentially expressed in AD brains. Using literature mining tools we have established (Figs. 2 and 3) many new gene associations, not yet reported to be involved in AD. This information will facilitate future efforts aimed at establishing alterations in molecular pathways involved AD pathology.

\section{Methods}

\section{Brain tissues and RNA extraction}

Poly A+ RNA was isolated from the frontal cortex of frozen post mortem human brains from the same $4 \mathrm{AD}$ and 5 age-matched control subjects as used in our previous study using the same the extraction procedure [34]. Equal amounts of mRNA were taken from each brain and subsequently combined to generate separate pools of AD RNA and normal RNA. Five micrograms of the mixed mRNA from each pool was converted to double-stranded cDNA (ds-cDNA) and used to prepare full-length tester and driver cDNA libraries.

\section{Subtractive Transcription-based Amplification of mRNA (STAR)}

The STAR subtraction procedure was performed as illustrated in Figure 1. Briefly, single stranded (+) sense tester RNA and single stranded (-) sense driver DNA were generated from specialized tester and driver cDNA libraries (see below), respectively. Subtraction was accomplished by hybridization of single-stranded driver cDNA to the complementary single-stranded tester RNA, followed by RNase $\mathrm{H}$ digestion. The unhybridized tester RNA remained active when subjected to a linear RNA amplification process comprising the steps of (i) reverse transcription, to synthesize cDNA from the tester RNA; (ii) DNA conversion, to append a promoter to the cDNA; and (iii) in vitro transcription, to synthesize additional copies of tester RNA.

\section{Construction of full length tester and driver CDNA libraries}

Double-stranded cDNA (ds-cDNA) was synthesized from $5 \mu \mathrm{g}$ of mRNA from each pool of brains using a modified ThermoScript $^{\mathrm{TM}}$ ds-cDNA synthesis kit (Invitrogen, Burlington, $\mathrm{ON}$ ) and a locking- $\mathrm{dT}_{19} \mathrm{~V}$ oligonucleotide comprising a Not I restriction enzyme site. An Asc I adaptor was then ligated to the 5' terminus of the ds-cDNA. Following digestion with Asc I and Not I enzymes (NEB, Pickering, ON), the ds-cDNA was directionally ligated into pUC18-derived vectors, $\mathrm{p} 17^{+}$for the production of driver DNA and p14 for the production of tester RNA. Both vectors contained a T7 promoter and specific oligonucleotide sequences (OGS302: 5'-GCCTGCACCAACAGTTAACA, in the case of $\mathrm{p}^{7}{ }^{+}$, and OGS77: 5'-CGAGAGCACCTGGATAGGTT, in the case of p14), immediately upstream of the cDNA inserts. These plasmids were then transformed into E. coli DH10B cells to generate the full length cDNA libraries.

\section{Construction of 3'-UTR tester and driver CDNA libraries}

Subtraction using STAR was performed using only the more variable 3'-UTR regions of mRNA sequences in order to minimize losses of gene family members that share homologous 5'-UTR and coding regions. Thus, 3'-UTR tester and driver libraries were subcloned from the original full-length p14 and p17+ cDNA libraries as follows. Plasmid DNA ( $2 \mu \mathrm{g}$ ) from each library was digested with Not I restriction enzyme and purified using Qiaquick (Qiagen, Mississauga, ON) and $1 \mu \mathrm{g}$ of each was used to in vitro transcribe (IVT) full-length RNA copies of the cDNA inserts with T7 RNA polymerase, according to the manufacturer's instruction (USB, Cleveland, $\mathrm{OH}$ ). The plasmid DNA template was digested with 2U RNase-free DNase I (Promega, Madison WI) and the RNA was purified with RNeasy kit (Qiagen). The newly synthesized RNA from each library now contained specific oligonucleotide sequences OGS77 and OGS302 at its 5' terminus, which were initially carried by $\mathrm{p} 14$ and $\mathrm{p} 17^{+}$plasmid vectors, respectively. Twenty micrograms of each IVT RNA were converted to first-strand cDNA (as described above) and purified by Qiaquick (Qiagen). Second-strand cDNA synthesis was then accomplished in a reaction containing Klenow DNA polymerase and specific oligonucleotide primers, OGS77 or OGS302, according to the manufacturer's instruction (NEB, Pickering, ON). The resulting full-length ds-DNA for each library was purified by Qiaquick (Qiagen). To prepare the 3'-UTR tester and driver libraries for STAR, $6 \mu \mathrm{g}$ of the full-length ds-DNA for each library was divided into $1 \mu \mathrm{g}$ aliquots and each aliquot was digested with one of six restriction enzymes (Bsh 1236 I, HinP1 I, Mse I, Msp I, Rsa I or Sau3A I) (NEB and MBI Fermentas, Burlington, ON). Following digestion, each set of 6 reactions was extracted with phenol, pooled and desalted. Each pooled DNA sample was bluntended using T4 DNA polymerase (NEB) and ligated to 2.5 $\mu \mathrm{g}$ Asc I linker (NEB) in a $10 \mu \mathrm{L}$ reaction. Each linkeradapted DNA sample was then digested with Asc I and Not I enzymes (NEB) and purified using Qiaquick (Qiagen). The digested DNA samples were then ligated into Asc I-Not I digested p14 and $\mathrm{p} 17^{+}$plasmid vectors respectively and transformed into E. coli DH10B cells. The resulting transformants for each library were pooled to produce the 3'-UTR p14-tester and p17-driver libraries.

\section{Construction of 3' STAR subtracted cDNA libraries}

One microgram of plasmid DNA isolated from each 3'UTR library was digested with Not I and purified by Qiaquick (Qiagen), and then in vitro transcribed as described above to produce RNA. The RNA copies from the tester library are now ready to be used in STAR. Twenty micrograms of the p17-3' driver RNA were further converted to single-stranded driver DNA in a first-strand cDNA synthesis reaction as described above with the exception that a oligo rU, instead of oligo dT, was used as 
primer for the cDNA synthesis and the rU primer attached to every first strand cDNA was then digested with RNase A. The p14-3' tester RNA (10 ng) was then hybridized with 100-fold excess p17-3' single-stranded driver DNA in a hybridization buffer containing $40 \mathrm{mM}$ Tris- $\mathrm{HCl}$, pH7.5, $0.1 \mathrm{M} \mathrm{NaCl}, 7.6 \%$ D-Trehalose and 40\% DMSO. The reaction was carried out in a thermocycler in descending temperature sequence as follows: $65^{\circ} \mathrm{C}, 63^{\circ} \mathrm{C}$ and $61^{\circ} \mathrm{C}$ each for $10 \mathrm{~min} ; 59^{\circ} \mathrm{C}$ for $30 \mathrm{~min} ; 57^{\circ} \mathrm{C}, 55^{\circ} \mathrm{C}, 53^{\circ} \mathrm{C}, 51^{\circ} \mathrm{C}$, $49^{\circ} \mathrm{C}, 47^{\circ} \mathrm{C}$ and $44.5^{\circ} \mathrm{C}$ each for $98 \mathrm{~min} ; 42.5^{\circ} \mathrm{C}$ for 18 hours, followed by RNase $\mathrm{H}$ digestion at $40^{\circ} \mathrm{C}$ for $30 \mathrm{~min}$. The tester RNA was then converted to cDNA and amplified by in vitro transcription as described above. After 3rounds of STAR (Fig. 1), the remaining tester RNA was converted to double-stranded DNA, digested with Asc I and Not I and ligated into a similarly digested pUC-modified vector. The plasmids containing specific tester DNA inserts were transformed into E. coli DH10B cells to form the STAR libraries.

\section{Analysis of STAR CDNA libraries from human brain samples}

A STAR library, where AD 3' cDNA was used as tester (termed the AD-C library) which should contain genes up-regulated in AD brains. Conversely, when control 3' cDNA was used as tester, we produced a C-AD library, which should permit the isolation of genes down regulated in AD. Approximately 600 individual colonies from each subtracted library were picked and the cloned inserts were amplified by PCR with HotStart Taq polymerase (Qiagen) using forward and reverse flanking primers on the vector. The PCR amplicons were purified using the Corning filter polystyrene 96-well plate system (Fisher Scientific, Ottawa, ON). One microliter of the purified PCR product was used for sequencing on the ABI Prism 377 DNA sequencer or 3100 Genetic Analyzer. DNA sequences were analyzed using Sequencher and batch BLAST search.

\section{CDNA synthesis, and $q R T-P C R$}

cDNA was synthesized from the same RNA pools used to construct the original AD and control cDNA libraries using Superscript II Reverse Transcriptase according to the manufacturer's instruction (Invitrogen). The reaction was stopped by adding EDTA to a final concentration of 5 mM. RNA templates were subsequently hydrolyzed in 0.5 $\mathrm{M} \mathrm{NaOH}$ solution at $65^{\circ} \mathrm{C}$ for $20 \mathrm{~min}$. The cDNA was further purified using a QIAquick PCR purification kit (Qiagen) and quantified using the OliGreen ssDNA Quantitation Kit (Molecular Probe, Hornby, ON). Forward and reverse primers for sequences of interest were designed using Primer Express (Applied Biosystems, Foster City, CA). Equal amounts of cDNA (2 ng each) were used for qRT-PCR analysis using the QuantiTect SYBR Green PCR Kit (Qiagen) according to the manufacturer's instructions. Fluorescent products were detected using a GeneAmp 5700 Sequence Detection System (PE Applied Biosystems). Percentage of changes was calculated according to the manufacturer's instruction. The experiments were performed in triplicate. Only significant differences ( $\rho<0.05$; t-test on the qRT-PCR experiments) between AD and control samples are reported as differentially expressed genes.

\section{Literature mining}

UniGene symbols of the known genes from each subtracted library were obtained from the SOURCE database using their respective Genbank accession numbers. These symbols were imported into a literature mining prototype software, LitMiner [64], developed by the National Research Council of Canada to identify relationships among genes and their association with biological processes. The search uses the standard UniGene symbols and all possible aliases appearing in the title, abstract or MeSH terms of publications. The associations amongst genes are represented as a graph with the frequency indicated by numbers on the links. Occasionally, the numbers in the graphs may not accurately represent associations because some articles might simply mention genes or terms without specifying an association or using incorrect or incomplete gene aliases. In practice these errors are manageable, because within LitMiner, we can rapidly retrieve and manually scan articles to eliminate such false associations. A knowledge term, such as "Alzheimer" or "Neurodegeneration" was added into the search to explore possible association of these genes with AD. The LitMiner tool was used since it is a much faster than searching for gene relationships manually. In this context, relationship means a co occurrence between either gene names or gene names and a biological process.

Every step performed with LitMiner for this study could be replicated manually using Entrez Gene, PubMed, and graph drawing tools available in Microsoft Word or similar sources. The first step of this manual process would be to find all the gene name aliases available in Entrez Gene for each known UniGene symbol from each subtracted library. Second, each such list of aliases would be converted into a disjunctive PubMed query by adding the OR operator ( $\mid$ ) after each alias. As well, any alias that is longer than a single word would be enclosed in quotation signs (" "). For example, part of the query for the gene A2M would be, "A2M" | "alpha 2 macroglobulin" | "alpha2 $M "$. Other manual improvements could be made to this query, i.e., to remove overly general terms. Third, researchers would scan the results removing incorrect or uninformative matches. Fourth, a database or file would record all the PMIDs that matched each of these gene queries in PubMed. Fifth, queries would be created for biological processes and the resulting lists of PMIDs would also 
be included in the database. Using this database, the researcher could then count how many PMIDs were shared by any pair of genes or biological process. For example, there would be tens of PMIDs whose title, abstract, and MeSH terms mention both A2M and APP. Once all co occurrence counts are collected, those counts could be entered into a manually drawn graph. These steps would require a considerable amount of time, to remove incorrect matches and to produce graphs of the co occurrences between gene names and biological processes.

\section{Authors' contributions}

QYL participated in the design of the study, analysis and interpretation of the data and preparation of the manuscript. RRS performed the STAR experiments and helped to analyze the data and draft the manuscript. LTM invented the STAR procedure and contributed to the interpretation of the data. MRL constructed the regular CDNA libraries, performed the qRT-PCR analysis. JXL and HS both participated in the qRT-PCR analysis and the interpretation of the data. BL provided comprehensively classified postmortem human control and AD brain tissues. JM developed LitMiner software and contributed to writing of the manuscript. PRW and MS both participated in the design of the study and contributed to writing of the manuscript. All authors read and approved the final manuscript.

\section{Acknowledgements}

Funding for this work has been provided to QYL, MRL, JXL, HS, MS and PRW through the National Research Council Genomics and Health Initiative. The authors would like to thank Mr. Brandon Smith and Dr. Galen Chen for their assistance in Genbank searches, Ms. Dao Ly and Ms. Ziying Liu for DNA sequencing, and Ms. Lynn Wei for assistance with the LitMiner software.

\section{References}

I. Colangelo V, Schurr J, Ball MJ, Pelaez RP, Bazan NG, Lukiw WJ: Gene expression profiling of I 2633 genes in Alzheimer hippocampal CAI: transcription and neurotrophic factor down-regulation and up-regulation of apoptotic and pro-inflammatory signaling. J Neurosci Res 2002, 70:462-473.

2. Ginsberg SD, Hemby SE, Lee VM, Eberwine JH, Trojanowski JQ: Expression profile of transcripts in Alzheimer's disease tangle-bearing CAI neurons. Ann Neurol 2000, 48:77-87.

3. Loring JF, Wen X, Lee JM, Seilhamer J, Somogyi R: A gene expression profile of Alzheimer's disease. DNA Cell Biol 200I, 20:683-695.

4. Ricciarelli R, d'Abramo C, Massone S, Marinari U, Pronzato M, Tabaton M: Microarray analysis in Alzheimer's disease and normal aging. IUBMB Life 2004, 56:349-354.

5. Pasinetti GM: Use of cDNA microarray in the search for molecular markers involved in the onset of Alzheimer's disease dementia. I Neurosci Res 2001, 65:47I -476.

6. Ho L, Sharma N, Blackman L, Festa E, Reddy G, Pasinetti GM: From proteomics to biomarker discovery in Alzheimer's disease. Brain Res Brain Res Rev 2005, 48:360-369.

7. Marcotte ER, Srivastava LK, Quirion R: cDNA microarray and proteomic approaches in the study of brain diseases: focus on schizophrenia and Alzheimer's disease. Pharmacol Ther 2003, 100:63-74.
8. Drmanac S, Stavropoulos NA, Labat I, Vonau J, Hauser B, Soares MB, Drmanac R: Gene-representing cDNA clusters defined by hybridization of 57,419 clones from infant brain libraries with short oligonucleotide probes. Genomics 1996, 37:29-40.

9. Milner RJ, Sutcliffe JG: Gene expression in rat brain. Nucleic Acids Res 1983, I I:5497-5520.

10. Liang P: A decade of differential display. Biotechniques 2002, 33:338-346.

II. Diatchenko L, Lau YF, Campbell AP, Chenchik A, Mogadam F, Huang B, Lukyanov S, Lukyanov K, Gurskaya N, Sverdlov ED, Siebert PD: Suppression subtractive hybridization: a method for generating differentially regulated or tissue-specific cDNA probes and libraries. Proc Natl Acad Sci USA 1996, 93:6025-6030.

12. Puskas LG, Zvara A, Hackler L Jr, Van Hummelen P: RNA amplification results in reproducible microarray data with slight ratio bias. Biotechniques 2002, 32:1330-1340.

13. Wang J, Hu L, Hamilton SR, Coombes KR, Zhang W: RNA amplification strategies for cDNA microarray experiments. Biotechniques 2003, 34:394-400.

14. Khalyfa A, Bourbeau D, Chen E, Petroulakis E, Pan J, Xu S, Wang E: Characterization of elongation factor-IA (eEFIA-I) and eEFIA-2/SI protein expression in normal and wasted mice. J Biol Chem 200I, 276:22915-22922.

15. Richardson JP, Mohammad SS, Pavitt GD: Mutations causing childhood ataxia with central nervous system hypomyelination reduce eukaryotic initiation factor 2B complex formation and activity. Mol Cell Biol 2004, 24:2352-2363.

16. Saunders AJ, Tanzi RE: Welcome to the complex disease world. Alpha2-macroglobulin and Alzheimer's disease. Exp Neurol 2003, 184:50-53.

17. van Leeuwen FW, de Kleijn DP, van den Hurk HH, Neubauer A, Sonnemans MA, Sluijs JA, Koycu S, Ramdjielal RD, Salehi A, Martens G], Grosveld FG, Peter J, Burbach H, Hol EM: Frameshift mutants of beta amyloid precursor protein and ubiquitin-B in Alzheimer's and Down patients. Science 1998, 279:242-247.

18. van Slegtenhorst M, Lewis J, Hutton M: The molecular genetics of the tauopathies. Exp Gerontol 2000, 35:46I-47I.

19. Vidal R, Calero M, Revesz T, Plant G, Ghiso J, Frangione B: Sequence, genomic structure and tissue expression of Human BRI3, a member of the BRI gene family. Gene 200I, 266:95-102.

20. Abdel-Rahman A, Rao MS, Shetty AK: Nestin expression in hippocampal astrocytes after injury depends on the age of the hippocampus. Glia 2004, 47:299-313.

21. Bhargava A, Meijer OC, Dallman MF, Pearce D: Plasma membrane calcium pump isoform I gene expression is repressed by corticosterone and stress in rat hippocampus. J Neurosci 2000 , 20:3|29-3|38.

22. Ito M, Depaz I, Wilce P, Suzuki T, Niwa S, Matsumoto I: Expression of human neuronal protein 22, a novel cytoskeleton-associated protein, was decreased in the anterior cingulate cortex of schizophrenia. Neurosci Lett 2005, 378: I25-I30.

23. Rajgopal $Y$, Vemuri MC: Ethanol induced changes in cyclindependent kinase-5 activity and its activators, P35, P67 (Munc-18) in rat brain. Neurosci Lett 2001, 308:173-176.

24. Sawada K, Young CE, Barr AM, Longworth K, Takahashi S, Arango V, Mann JJ, Dwork AJ, Falkai P, Phillips AG, Honer WG: Altered immunoreactivity of complexin protein in prefrontal cortex in severe mental illness. Mol Psychiatry 2002, 7:484-492.

25. Shimura H, Schwartz D, Gygi SP, Kosik KS: CHIP-Hsc70 complex ubiquitinates phosphorylated tau and enhances cell survival. J Biol Chem 2004, 279:4869-4876.

26. Sook KM, Hyen BJ, Bae MK, Kim KW: Human rad2I gene, hHR2I(SP), is downregulated by hypoxia in human tumor cells. Biochem Biophys Res Commun 200 I, 28 I: I I06-I I I 2

27. Fatemi SH, Snow AV, Stary JM, Araghi-Niknam M, Reutiman TJ, Lee S, Brooks Al, Pearce DA: Reelin signaling is impaired in autism. Biol Psychiatry 2005, 57:777-787.

28. Zhu G, Wang D, Lin YH, McMahon T, Koo EH, Messing RO: Protein kinase $\mathrm{C}$ epsilon suppresses Abeta production and promotes activation of alpha-secretase. Biochem Biophys Res Commun 200I, 285:997-1006.

29. Duguid JR, Bohmont CW, Liu NG, Tourtellotte WW: Changes in brain gene expression shared by scrapie and Alzheimer disease. Proc Natl Acad Sci USA 1989, 86:7260-7264. 
30. May PC, Finch CE: Sulfated glycoprotein 2: new relationships of this multifunctional protein to neurodegeneration. Trends Neurosci 1992, I 5:391-396.

31. Mocchegiani E, Giacconi R, Fattoretti P, Casoli T, Cipriano C, Muti E, Malavolta M, DiStefano G, Bertoni-Freddari C: Metallothionein isoforms (I+II and III) and interleukin-6 in the hippocampus of old rats: may their concomitant increments lead to neurodegeneration? Brain Res Bull 2004, 63: |33-|42.

32. Takahashi M, Iseki E, Kosaka K: Cdk5 and munc- I 8/p67 co-localization in early stage neurofibrillary tangles-bearing neurons in Alzheimer type dementia brains. J Neurol Sci 2000, 1 72:63-69.

33. Dieterich DC, Bockers TM, Gundelfinger ED, Kreutz MR: Screening for differentially expressed genes in the rat inner retina and optic nerve after optic nerve crush. Neurosci Lett 2002, 3 1 7:29-32.

34. Walker PR, Smith B, Liu QY, Famili AF, Valdes JJ, Liu Z, Lach B: Data mining of gene expression changes in Alzheimer brain. Artif Intell Med 2004, 3 I: 137-154.

35. Fonseca S, Hackler J, Zvara A, Ferreira S, Balde A, Dudits D, Pais MS, Puskas LG: Monitoring gene expression along pear fruit development, ripening and senescence using cDNA microarrays. Plant Science 2004, I 67:457-469.

36. Kuperstein F, Yakubov E, Dinerman P, Gil S, Eylam R, Salem N Jr, Yavin E: Overexpression of dopamine receptor genes and their products in the postnatal rat brain following materna n-3 fatty acid dietary deficiency. I Neurochem 2005, 95: $1550-1562$

37. Bigl M, Apelt J, Eschrich K, Schliebs R: Cortical glucose metabolism is altered in aged transgenic Tg2576 mice that demonstrate Alzheimer plaque pathology. I Neural Transm 2003, I I 0:77-94

38. Fukuda M, Kanno E, Ogata Y, Saegusa C, Kim T, Loh YP, Yamamoto A: Nerve growth factor-dependent sorting of synaptotagmin IV protein to mature dense-core vesicles that undergo calcium-dependent exocytosis in PCI 2 cells. J Biol Chem 2003 278:3220-3226.

39. Janz R, Goda Y, Geppert M, Missler M, Sudhof TC: SV2A and SV2B function as redundant $\mathrm{Ca2}+$ regulators in neurotransmitter release. Neuron 1999, 24:1003-1016.

40. Nixon RA, Saito KI, Grynspan F, Griffin WR, Katayama S, Honda T, Mohan PS, Shea TB, Beermann M: Calcium-activated neutral proteinase (calpain) system in aging and Alzheimer's disease. Ann N Y Acad Sci 1994, 747:77-91.

41. Wagner SL, Geddes JW, Cotman CW, Lau AL, Gurwitz D, Isackson PJ, Cunningham DD: Protease nexin-I, an antithrombin with neurite outgrowth activity, is reduced in Alzheimer disease. Proc Natl Acad Sci USA 1989, 86:8284-8288.

42. Selkoe DJ: Alzheimer's disease is a synaptic failure. Science 2002, 298:789-791.

43. Castegna A, Aksenov M, Thongboonkerd V, Klein JB, Pierce WM, Booze R, Markesbery WR, Butterfield DA: Proteomic identification of oxidatively modified proteins in Alzheimer's disease brain. Part II: dihydropyrimidinase-related protein 2, alphaenolase and heat shock cognate 7I. J Neurochem 2002 , 82: I524- I532.

44. Shen H, Sikorska M, Leblanc J, Walker PR, Liu QY: Oxidative stress regulated expression of Ubiquitin Carboxyl-terminal Hydrolase-LI: Role in cell survival. Apoptosis 2006 in press.

45. Caballero OL, Resto V, Patturajan M, Meerzaman D, Guo MZ, Engles J, Yochem R, Ratovitski E, Sidransky D, Jen J: Interaction and colocalization of PGP9.5 with JAB I and p27(Kip I). Oncogene 2002, 2 I:3003-3010

46. Ramanathan $M$, Hassanain $M$, Levitt $M$, Seth A, Tolman JS, Fried VA Ingoglia NA: Oxidative stress increases ubiquitin - protein conjugates in synaptosomes. Neuroreport 1999, 10:3797-3802.

47. Vannucci SJ, Mummery R, Hawkes RB, Rider CC, Beesley PW: Hypoxia-ischemia induces a rapid elevation of ubiquitin conjugate levels and ubiquitin immunoreactivity in the immature rat brain. I Cereb Blood Flow Metab 1998, I 8:376-385.

48. Lue LF, Brachova L, Civin WH, Rogers J: Inflammation, A beta deposition, and neurofibrillary tangle formation as correlates of Alzheimer's disease neurodegeneration. J Neuropathol Exp Neurol 1996, 55:1083-1088.
49. Macq AF, Goossens F, Maloteaux JM, Octave JN: Overexpression of the myelin basic protein RNA in the cortex of a patient with Alzheimer's disease. Acta Neurol Belg 1989, 89:316.

50. McGeer EG, Yasojima K, Schwab C, McGeer PL: The pentraxins: possible role in Alzheimer's disease and other innate inflammatory diseases. Neurobiol Aging 200I, 22:843-848.

5I. Yesner LM, Huh HY, Pearce SF, Silverstein RL: Regulation of monocyte CD36 and thrombospondin-I expression by soluble mediators. Arterioscler Thromb Vasc Biol 1996, 16:1019-1025.

52. Connor JR, Menzies SL, St Martin SM, Mufson EJ: A histochemical study of iron, transferrin, and ferritin in Alzheimer's diseased brains. I Neurosci Res 1992, 31:75-83.

53. Loeffler DA, LeWitt PA, Juneau PL, Sima AA, Nguyen HU, DeMaggio AJ, Brickman CM, Brewer GJ, Dick RD, Troyer MD, Kanaley L: Increased regional brain concentrations of ceruloplasmin in neurodegenerative disorders. Brain Res 1996, 738:265-274.

54. Debril MB, Dubuquoy L, Feige JN, Wahli W, Desvergne B, Auwerx J Gelman L: Scaffold attachment factor BI directly interacts with nuclear receptors in living cells and represses transcriptional activity. I Mol Endocrinol 2005, 35:503-5।7.

55. Broers JL, Kuijpers HJ, Ostlund C, Worman HJ, Endert J, Ramaekers FC: Both lamin A and lamin $\mathbf{C}$ mutations cause lamina instability as well as loss of internal nuclear lamin organization. Exp Cell Res 2005, 304:582-592.

56. Stankewich MC, Tse WT, Peters LL, Ch'ng Y, John KM, Stabach PR, Devarajan P, Morrow JS, Lux SE: A widely expressed betallI spectrin associated with Golgi and cytoplasmic vesicles. Proc Natl Acad Sci USA 1998, 95:14158-14163.

57. Avramut $M$, Achim $C L$ : Immunophilins and their ligands: insights into survival and growth of human neurons. Physiol Behav 2002, 77:463-468.

58. Farah CA, Liazoghli D, Perreault S, Desjardins M, Guimont A, Anton A, Lauzon M, Kreibich G, Paiement J, Leclerc N: Interaction of microtubule-associated protein-2 and p63: a new link between microtubules and rough endoplasmic reticulum membranes in neurons. J Biol Chem 2005, 280:9439-9449.

59. Cyr JL, Pfister KK, Bloom GS, Slaughter CA, Brady ST: Molecular genetics of kinesin light chains: generation of isoforms by alternative splicing. Proc Natl Acad Sci USA 1991, 88:10114-10118.

60. Zhu X, Raina AK, Boux H, Simmons ZL, Takeda A, Smith MA: Activation of oncogenic pathways in degenerating neurons in Alzheimer disease. Int ] Dev Neurosci 2000, I 8:433-437.

61. Nie Z, Stanley KT, Stauffer S, Jacques KM, Hirsch DS, Takei J, Randazzo PA: AGAPI, an endosome-associated, phosphoinositide-dependent ADP-ribosylation factor GTPaseactivating protein that affects actin cytoskeleton. J Biol Chem 2002, 277:48965-48975.

62. Madura T, Yamashita T, Kubo T, Tsuji L, Hosokawa K, Tohyama M Changes in mRNA of Slit-Robo GTPase-activating protein 2 following facial nerve transection. Brain Res Mol Brain Res 2004, I 23:76-80.

63. Kremer BE, Haystead T, Macara IG: Mammalian septins regulate microtubule stability through interaction with the microtubule-binding protein MAP4. Mol Biol Cell 2005, I6:4648-4659.

64. de Bruijn B, Martin J: Finding gene function using LitMiner. Proc Text Retrieval Conference (TREC) 2003:45 I-459.

65. Engidawork E, Gulesserian T, Fountoulakis M, Lubec G: Aberrant protein expression in cerebral cortex of fetus with Down syndrome. Neuroscience 2003, I 22: | 45- I 54.

66. Yang LB, Li R, Meri S, Rogers J, Shen Y: Deficiency of complement defense protein CD59 may contribute to neurodegeneration in Alzheimer's disease. I Neurosci 2000, 20:7505-7509.

67. Liauw J, Nguyen V, Huang J, George-Hyslop P, Rozmahel R: Differential display analysis of presenilin I-deficient mouse brains. Brain Res Mol Brain Res 2002, I 09:56-62.

68. Sorbi S, Mortilla M, Piacentini S, Tonini S, Amaducci L: Altered hexokinase activity in skin cultured fibroblasts and leukocytes from Alzheimer's disease patients. Neurosci Lett 1990, I | 7:165-168.

69. Fernandes ML, Saad MJ, Velloso LA: Effects of age on elements of insulin-signaling pathway in central nervous system of rats. Endocrine 2001, 1 6:227-234.

70. Morley JE: The SAMP8 mouse: a model of Alzheimer disease? Biogerontology 2002, 3:57-60.

7I. Choi J, Levey AI, Weintraub ST, Rees HD, Gearing M, Chin LS, Li L Oxidative modifications and down-regulation of ubiquitin 
carboxyl-terminal hydrolase LI associated with idiopathic Parkinson's and Alzheimer's diseases. J Biol Chem 2004, 279: 13256-13264.

72. Kurihara LJ, Kikuchi T, Wada K, Tilghman SM: Loss of Uch-LI and Uch-L3 leads to neurodegeneration, posterior paralysis and dysphagia. Hum Mol Genet 200I, I0:1963-1970.

73. Masliah E, Roberts ES, Langford D, Everall I, Crews L, Adame A, Rockenstein E, Fox HS: Patterns of gene dysregulation in the frontal cortex of patients with HIV encephalitis. J Neuroimmunol 2004, 157:163-175.

74. Ferrer I, Barrachina M, Puig B, Martinez dL, Marti E, Avila J, Dierssen $M$ : Constitutive DyrkIA is abnormally expressed in Alzheimer disease, Down syndrome, Pick disease, and related transgenic models. Neurobiol Dis 2005, 20:392-400.

75. Mathews PM, Guerra CB, Jiang Y, Grbovic OM, Kao BH, Schmidt SD, Dinakar R, Mercken M, Hille-Rehfeld A, Rohrer J, Mehta P, Cataldo AM, Nixon RA: Alzheimer's disease-related overexpression of the cation-dependent mannose 6-phosphate receptor increases Abeta secretion: role for altered lysosomal hydrolase distribution in beta-amyloidogenesis. J Biol Chem 2002, 277:5299-5307.

76. Hata R, Masumura M, Akatsu H, Li F, Fujita H, Nagai Y, Yamamoto T, Okada $\mathrm{H}$, Kosaka K, Sakanaka M, Sawada T: Up-regulation of calcineurin Abeta mRNA in the Alzheimer's disease brain: assessment by cDNA microarray. Biochem Biophys Res Commun 200I, 284:310-316

77. Yoo BC, Fountoulakis M, Cairns N, Lubec G: Changes of voltagedependent anion-selective channel proteins VDACI and VDAC2 brain levels in patients with Alzheimer's disease and Down syndrome. Electrophoresis 200I, 22:172-179.

78. Fountoulakis M, Cairns N, Lubec G: Increased levels of 14-3-3 gamma and epsilon proteins in brain of patients with Alzheimer's disease and Down syndrome. J Neural Transm Suppl I999, 57:323-335.

79. Larkin JE, Frank BC, Gaspard RM, Duka I, Gavras H, Quackenbush J: Cardiac transcriptional response to acute and chronic angiotensin II treatments. Physiol Genomics 2004, 18: I 52-166.

80. Shin JH, Weitzdoerfer R, Fountoulakis M, Lubec G: Expression of cystathionine beta-synthase, pyridoxal kinase, and ESI protein homolog (mitochondrial precursor) in fetal Down syndrome brain. Neurochem Int 2004, 45:73-79.

81. Koh PO, Undie AS, Kabbani N, Levenson R, Goldman-Rakic PS, Lidow MS: Up-regulation of neuronal calcium sensor-I (NCS-I) in the prefrontal cortex of schizophrenic and bipolar patients. Proc Natl Acad Sci USA 2003, 100:313-317.

82. Rosdahl D, Seitzberg DA, Christensen T, Balchen T, Diemer NH: Changes in mRNA for metabotropic glutamate receptors after transient cerebral ischaemia. Neuroreport 1994, 5:593-596.

83. Perez-Torres S, Cortes R, Tolnay M, Probst A, Palacios JM, Mengod G: Alterations on phosphodiesterase type 7 and 8 isozyme mRNA expression in Alzheimer's disease brains examined by in situ hybridization. Exp Neurol 2003, 182:322-334.

84. Bai J, He F, Novikova SI, Undie AS, Dracheva S, Haroutunian V, Lidow MS: Abnormalities in the dopamine system in schizophrenia may lie in altered levels of dopamine receptor-interacting proteins. Biol Psychiatry 2004, 56:427-440.

85. Timm T, Li XY, Biernat J, Jiao J, Mandelkow E, Vandekerckhove J, Mandelkow EM: MARKK, a Ste20-like kinase, activates the polarity-inducing kinase MARK/PAR-I. EMBO J 2003, 22:5090-5I0I.

86. Pollak D, Weitzdoerfer R, Yang YW, Prast H, Hoeger H, Lubec G: Cerebellar protein expression in three different mouse strains and their relevance for motor performance. Neurochem Int 2005, 46: 19-29.

87. Li J, Pauley AM, Myers RL, Shuang R, Brashler JR, Yan R, Buhl AE, Ruble C, Gurney ME: SEL- 10 interacts with presenilin I, facilitates its ubiquitination, and alters A-beta peptide production. J Neurochem 2002, 82:1540-I548.

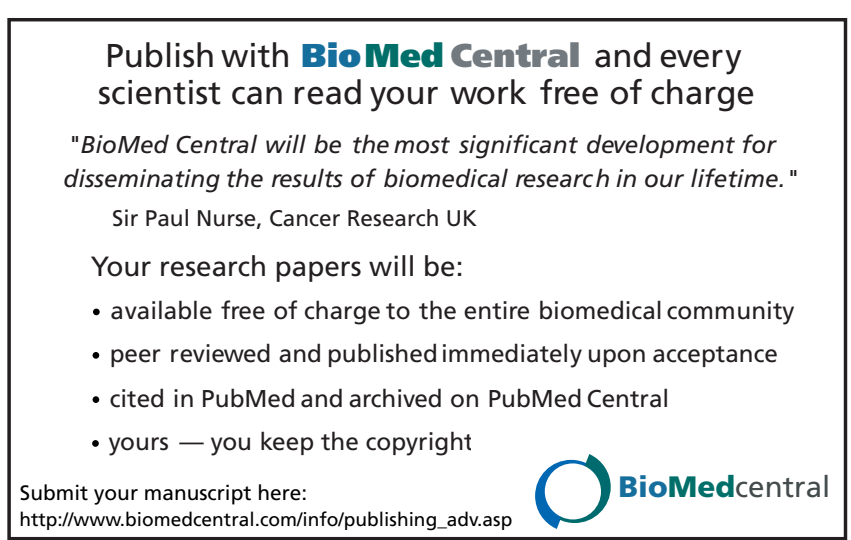

